\title{
POL-TAVI - Polish Registry of Transcatheter Aortic Valve Implantation - simple tool, great value, rationale and design
}

\author{
Joanna Zembala-John ${ }^{1,2,3}$, Krzysztof Wilczek ${ }^{4}$, Zdzisław Tobota ${ }^{5}$, Piotr Chodór ${ }^{6}$, Daniel Cieśla ${ }^{7}$, Tomasz Jaźwiec ${ }^{8}$, \\ Waldemar Banasiak ${ }^{9}$, Janina Stępińska ${ }^{10}$, Zbigniew Kalarus ${ }^{6}$, Grzegorz Opolski ${ }^{11}$, Marian Zembala ${ }^{8}$
}

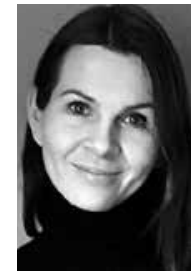

\author{
${ }^{1}$ Silesian Center for Heart Diseases in Zabrze, Poland \\ ${ }^{2}$ Department of Doctoral Studies, School of Public Health in Bytom, Medical University of Silesia in Katowice, Poland \\ ${ }^{3}$ Kardio-Med Silesia Science and Technology Park, Zabrze, Poland \\ ${ }^{4} 3^{\text {rd }}$ Department of Cardiology, School of Medicine with the Division of Dentistry in Zabrze, Medical University of Silesia \\ in Katowice, Silesian Center for Heart Diseases, Zabrze, Poland \\ ${ }^{5}$ Department of Cardiothoracic Surgery, The Children's Memorial Health Institute, Warsaw, Poland \\ ${ }^{6}$ Department of Cardiology, Congenital Heart Diseases and Electrotherapy, Medical University of Silesia in Katowice, \\ Silesian Center for Heart Diseases in Zabrze, Poland \\ ${ }^{7}$ Center for Research, Training and New Medical Technologies, Silesian Centre for Heart Diseases, Zabrze, Poland \\ ${ }^{8}$ Department of Cardiac, Vascular and Endovascular Surgery and Transplantology, Medical University of Silesia in Katowice, \\ Silesian Center for Heart Diseases in Zabrze, Poland \\ ${ }^{9}$ Department of Cardiology, Military Hospital, Wroclaw, Poland \\ ${ }^{10}$ Department of Intensive Cardiac Care, Institute of Cardiology, Warsaw, Poland \\ ${ }^{11} 1^{\text {st }}$ Department of Cardiology, Warsaw Medical University, Warsaw, Poland
}

Kardiochirurgia i Torakochirurgia Polska 2016; 13 (4): 309-315

\begin{abstract}
Aortic stenosis (AS) is the most common valvular heart disease in adults in Europe and North America. Management of AS patients depends on accurate diagnosis of the cause and stage of the disease process: the first and definitive therapeutic choice for a growing number of elderly patients with symptomatic AS is surgical treatment. In patients not eligible for surgery, transcatheter aortic valve implantation (TAVI) constitutes a safe and effective alternative. As an innovative, costly method of treatment, it requires however careful monitoring of its course, documenting its early and long-term results, and assessment of its safety and medical-economic cost-effectiveness. A medical registry seems to be an excellent tool to perform such analysis.

The aim of this paper is to present the design and rationale for creation of the first National Cardiac-Cardiac Surgical Registry of Percutaneous Aortic Valve Treatment POL-TAVI, to describe its genesis and to highlight its key assumptions and aims.

Despite its recent beginnings, the POL-TAVI Registry has already demonstrated its value and usability in monitoring and assessment of TAVI procedures, leading to further improvement and development of this new method in Poland. It constitutes an important and valuable tool for patients, the medical community and the payer.
\end{abstract}

Key words: transcatheter aortic valve implantation, registry, POL-TAVI, aortic stenosis, cost-effectiveness.

\section{Streszczenie}

Stenoza aortalna należy do najczęstszych wad zastawkowych u dorosłych w Europie i Ameryce Północnej. Postępowanie lecznicze $w$ tej grupie pacjentów zależy od etiologii i stopnia zaawansowania choroby. Główną metodą terapeutyczną u zwiększającej się liczby starszych chorych z objawową stenozą aortalną jest chirurgiczna implantacja zastawki aortalnej. U chorych wykluczonych z leczenia chirurgicznego bezpieczną i skuteczną alternatywę stanowi przezcewnikowe wszczepienie zastawki aortalnej. Jest to metoda nowa, kosztowna i jako taka wymagająca szczególnie uważnego, systematycznego monitorowania przebiegu, wczesnych i odległych wyników leczenia, oceny jej bezpieczeństwa, jakości oraz medyczno-ekonomicznej efektywności kosztów. Rejestr medyczny wydaje się doskonałym narzędziem do prowadzenia takich analiz.

Celem pracy jest przedstawienie przesłanek do powstania pierwszego Ogólnopolskiego Kardiologiczno-Kardiochirurgicznego Rejestru Przezcewnikowych Implantacji Zastawek Aortalnych POL-TAVI, przybliżenie genezy rejestru, jego głównych założeń i celów, potencjalnych korzyści, jak również pokazanie architektury - rozwiązań projektowych Rejestru.

Rejestr POL-TAVI stanowi wartościowe i przydatne narzędzie do monitorowania i oceny programu TAVI w kraju, które służy leczonym, leczącym i organizującym leczenie. Wyniki Rejestru, będące przedmiotem wielopoziomowych analiz i ocen, przyczyniają się do dalszej poprawy i rozwoju tej metody w Polsce Słowa kluczowe: przezcewnikowa implantacja zastawki aortalnej, rejestr, POL-TAVI, stenoza aortalna, efektywność kosztów.

Address for correspondence: Joanna Zembala-John, Silesian Center for Heart Diseases, 9 M. Curie-Skłodowskiej St, 41-800 Zabrze, Poland, phone: +48 600255 343, e-mail: jzembala@wp.pl

Received: 24.11.2016, accepted: 20.12.2016. 


\section{Introduction}

Aortic stenosis (AS) is the most common valvular heart disease in adults in Europe and North America. Its prevalence in the community increases with age [1], currently at about 5\% (severe AS) in the population aged 75 and over [2].

Management of patients with AS depends on accurate diagnosis of the cause and stage of the disease process [3]. The first and definitive therapeutic choice for a growing number of elderly patients with symptomatic AS is surgical treatment (surgical aortic valve replacement - SAVR), performed either conventionally or mini-invasively, using different types of valves, mainly biological (including stentless and sutureless).

This method however is associated with elevated risk in approximately $1 / 3$ of patients with severe symptomatic AS (40\%) [4]. Although operative mortality of SAVR is low in a selective group of elderly patients, it increases with number and severity of co-morbidities [5]. Transcatheter aortic valve implantation (TAVI) constitutes a safe and effective therapeutic alternative for this population. As an innovative, costly method of treatment, it requires however

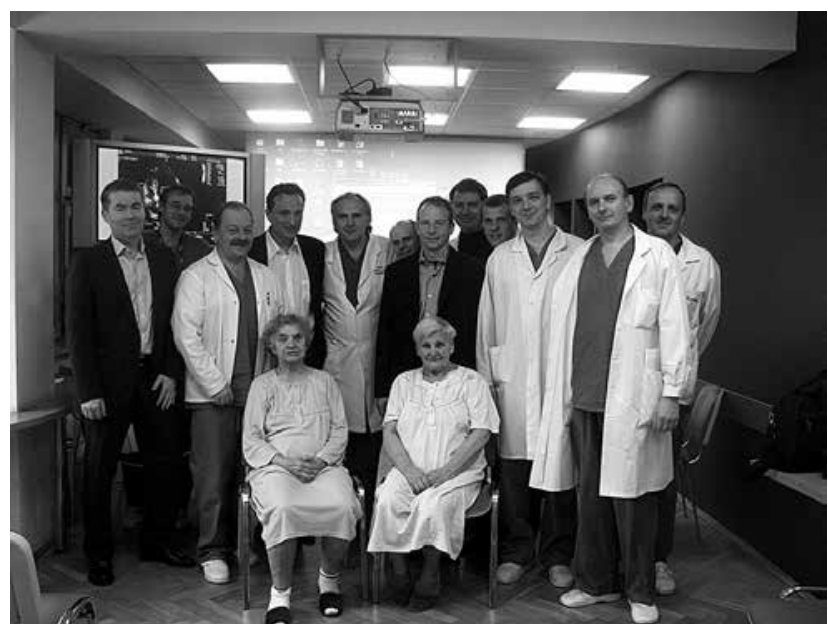

Fig. 1. First TAVI patients with Zabrze TAVI team and Matthias Thielmann (Essen, Germany) as proctor, Zabrze, November $26^{\text {th }}$, 2008. Source: SCCS archives

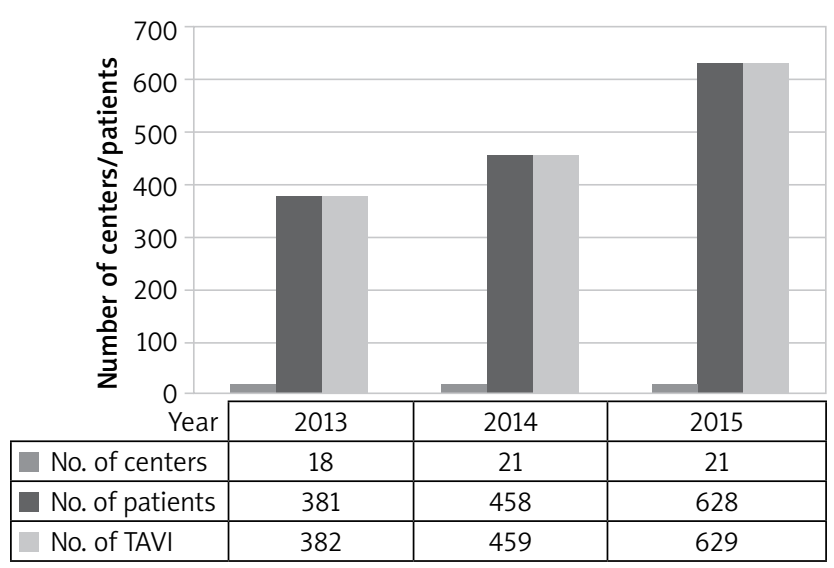

Fig. 2. Development of TAVI in Poland in years 2013-2015 - data from POL-TAVI Registry careful monitoring of its course, documenting its early and long-term results, assessment of its safety and medicaleconomic cost-effectiveness. A medical registry seems to be an excellent tool to perform such analysis.

\section{TAVI Program in Poland}

The transcatheter aortic valve procedure was introduced in Poland in 2008, initially in two centers: the John Paul II Hospital in Krakow and the Silesian Center for Heart Diseases in Zabrze. The first Polish TAVI from the transapical approach was performed in Krakow, and the first from the transfemoral approach in Zabrze. The first patients were three elderly women (a 77-year old who underwent the procedure in Krakow and a 77- and 76-year old in Zabrze) with severe symptomatic AS, non-eligible for SAVR due to co-morbidities (Fig. 1). Within a short period of time, from November 25 to March 30, 2009, 19 TAVI procedures were performed, in four Polish centers (aforementioned Silesian Center for Heart Diseases in Zabrze, John Paul II Hospital in Krakow, Institute of Cardiology in Warsaw and Upper Silesian Medical Center in Katowice). Results of those first implantations were presented in the POL-TAVI First Report [6].

Success of the first percutaneous aortic valve implantations resulted in launching the TAVI program in other centers across Poland authorized by the Ministry of Health, and later the National Health Fund. In 2012 there were 11 active TAVI centers, and in 2013 there were 18. Since 2014 the TAVI program has been conducted in 21 hospitals and the number of procedures has systematically increased (Fig. 2).

\section{TAVI application vs. recommendation}

Initially TAVI was recommended for end-stage patients with severe symptomatic AS [7]. With increased clinical application, and further device market development, TAVI has become a common therapeutic option for high-risk patients, unsuitable for surgery. In some countries, however, increased experience and good clinical short- and mediumterm results have led to an undesired increase in TAVI application, performed, regardless of recommendations, also in intermediate-risk patients (e.g. porcelain aorta) [8]. Studies confirm that the observed shift in number of TAVI procedures often results also from inappropriate qualification criteria on the basis of which patients are being referred for TAVI (e.g. advanced age solely) [9].

The large Euro Heart Survey on Valvular Heart Disease and other trials confirmed the existing gap between guidelines and real application of TAVI in clinical practice [4].

These observations resulted in development of the updated ESC/EACTS Guidelines on Vascular Heart Disease Management (2012), where indications and contraindications to TAVI were clearly defined.

The results of those studies revealed and stressed also urgent need for development of registries - a tool allowing collecting and monitoring the adherence to the guidelines, frequency of TAVI application, analysis of treatment course, and evaluation of efficacy of early and long-term outcomes. 


\section{Aim}

The aim of this paper is to present the design and rationale for creation of the first National Cardiac-Cardiac Surgical Registry of Percutaneous Aortic Valve Treatment POL-TAVI, to describe its genesis and to highlight its key assumptions, aims and potential benefits for patients, medical professionals, and the payer.

\section{Material and methods \\ Genesis and development of POL-TAVI Registry}

The aforementioned POL-TAVI First Report was the first medical-economic analysis of transcatheter aortic valve implantation in Poland. The aim of this report was to monitor and evaluate treatment outcomes, safety, quality and costeffectiveness of this innovative, costly method of treatment in Poland.

By 2011, almost every Polish center authorized by the Ministry of Health to perform TAVI conducted its own internal TAVI registry, designed according to its own project and its own clinical-scientific and organizational needs. Such a solution had enabled heart teams to monitor and assess their treatment outcomes; lack of unification and standardization, however, made comparison of treatment results with other Polish and foreign centers difficult and often unreliable.

When in 2010 on the initiative of the European Society of Cardiology, within the EurObservational Research Program, the Transcatheter Valve Treatment Registry (TCVT) was created, Poland was one of 12 countries that applied for enrolment. Within 2011-2012, the TCVT Pilot Registry, conducted under the leadership of Carlo di Mario, collected data on 4571 TAVI patients across Europe [10].

The participation of Poland (back then of all 11 Polish TAVI centers) in the TCVT Pilot Registry, converted later into a long-term registry, allowed for the first time for unification of the TAVI dataset, and credible assessment of national TAVI outcomes on the broader scale, including in comparison with other European centers.

Experience gained from the TCVT-Pilot Registry, but also from successful coordination of national, large, long-term registries, such as AMI-PL (National Database of Myocardial Infarction) and KROK (National Registry of Cardiac Surgery), resulted in development of the Polish TAVI registry. In 2013, on the initiative of Marian Zembala, national TAVI coordinator and long-term national consultant in cardiac surgery, as well as Waldemar Banasiak, president of the Polish Cardiac Society at the time, the first nation-wide Cardiac-Cardiac Surgical Registry of Transcatheter Aortic Valve Implantation - POL-TAVI - was launched. The initiative was strongly supported by the European Society of Cardiology, TCVT Registry leaders and the previous and present Board of the Polish Cardiac Society.

To ensure high quality, reliability and proper management of the Registry, the Steering Committee, composed of representatives of the leading Polish TAVI centers, car- diology and cardiac surgery domains, was constituted. It has been governed by Marian Zembala (chairman), Janina Stępińska (vice chairman), Grzegorz Opolski (vice chairman), Adam Witkowski (secretary) and members: Waldemar Banasiak, Dariusz Dudek, Krzysztof Filipiak, Piotr Hoffman, Zbigniew Kalarus, Bogusław Kapelak, Tomasz Kukulski, Bohdan Maruszewski, Andrzej Ochała, Piotr Olszówka, Jan Rogowski, Piotr Szymański and Krzysztof Wilczek. In addition, a POL-TAVI working group - an auditing team, including authors of this paper - was set up to monitor the completeness and quality of data reported.

\section{Rationale and purposes of POL-TAVI Registry}

Development of the POL-TAVI Registry was based on the following key assumptions:

- reporting to the registry will be obligatory for all TAVI hospitals and constitutes one of the conditions of contract for TAVI between a given center and a payer;

- registry will enable collection of all TAVI data in one place, in one standardized pattern;

- POL-TAVI will serve both clinicians and the payer as a national benchmark of treatment outcomes;

- credibility and completeness of data will be verified through internal and external regular audits. Moreover, systematic national audits of mortality reports will be performed;

- the Registry will serve as a national database for scientific purposes (material for publications, reports, presentations at national and international meetings), enabling dissemination of Polish results and promotion of the Polish TAVI program worldwide.

Furthermore, key messages - tasks of the POL-TAVI Registry - were set up: the main aim of the Registry is to assess and develop optimal management of severe symptomatic AS, a condition which has and will have, due to the aging population, a significant impact on society, and on the medical, economic and social burden of valvular heart disease in Poland.

The specific aims of the registry can be summarized as follows:

- to monitor TAVI indications and procedural strategy (access site, device distribution, type of anaesthesia);

- to supervise adherence to the guidelines and compliance with indications/contraindications to TAVI (exclude excessive application of costly devices, exclude inappropriate application of TAVI in patients too sick to benefit in terms of mortality and quality of life) (following TCVT Registry assumptions and indications);

- to assess objectively and non-commercially peri-procedural device success;

- to monitor and improve safety, quality and efficacy of treatment;

- to assess early- and long-term results of this novel method of treatment in order to develop the most optimal therapeutic follow-up strategy;

- to monitor and evaluate cost-effectiveness of TAVI in Poland; 


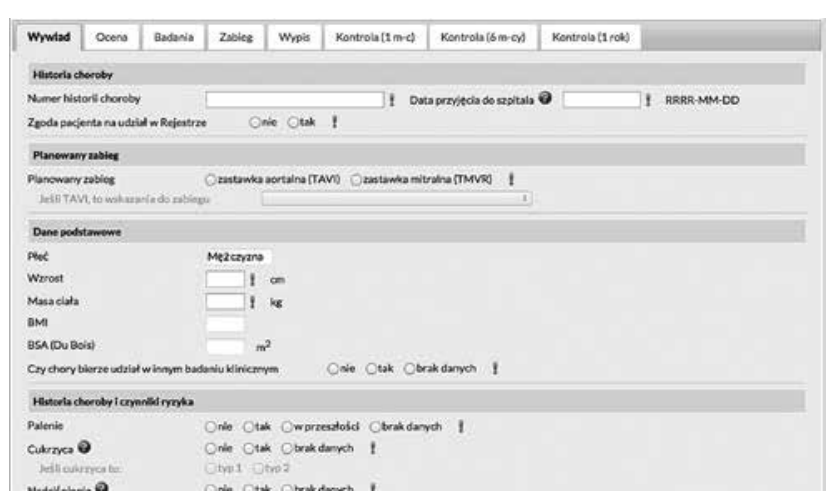

Fig. 3. Interview - patient profile: medical history, risk factors

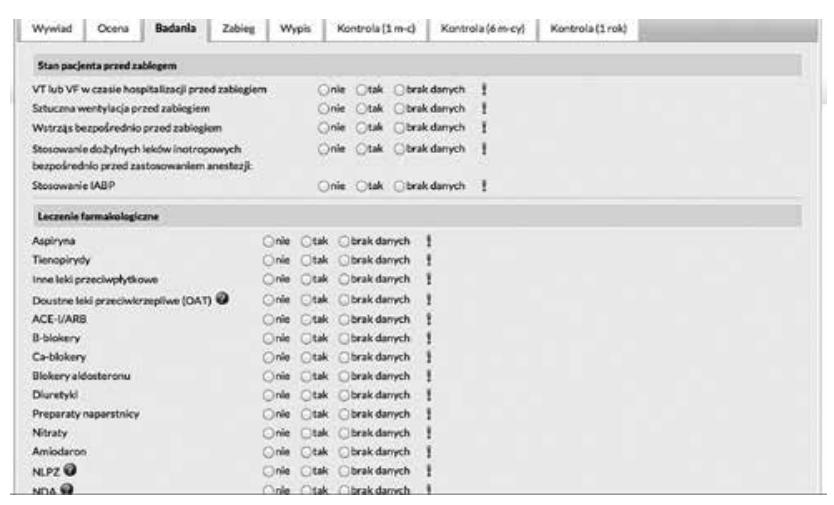

Fig. 5. Pre-procedural examination

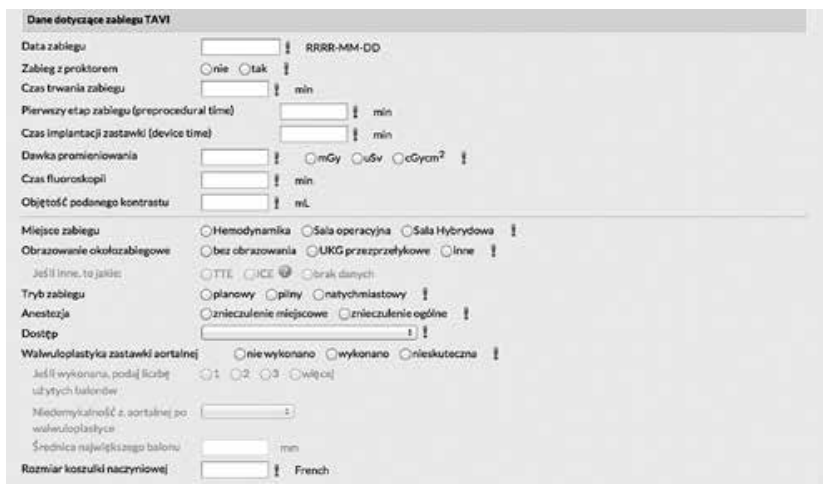

Fig. 7. Documentation of TAVI procedure

- to ensure the decision for TAVI is made by a multi-disciplinary heart team (in accordance with guidelines) to guarantee the optimal treatment of patients with severe symptomatic AS;

- based on the results of POL-TAVI, to continue development and improvement of this therapeutic method in Poland.

\section{Results}

\section{POL-TAVI Registry: design, dataset}

First POL-TAVI CRF, created by the authors, was largely based on well-proven European TCVT Registry forms (approval of TCVT Registry leaders was obtained). The electronic database was developed by MAGNUM 2, a company with extensive documented experience in development

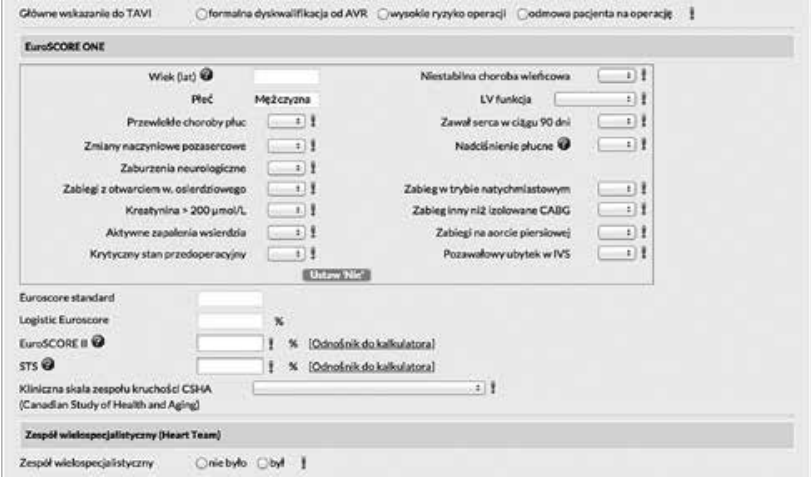

Fig. 4. TAVI Heart Team assessment: indications and contraindications to TAVI

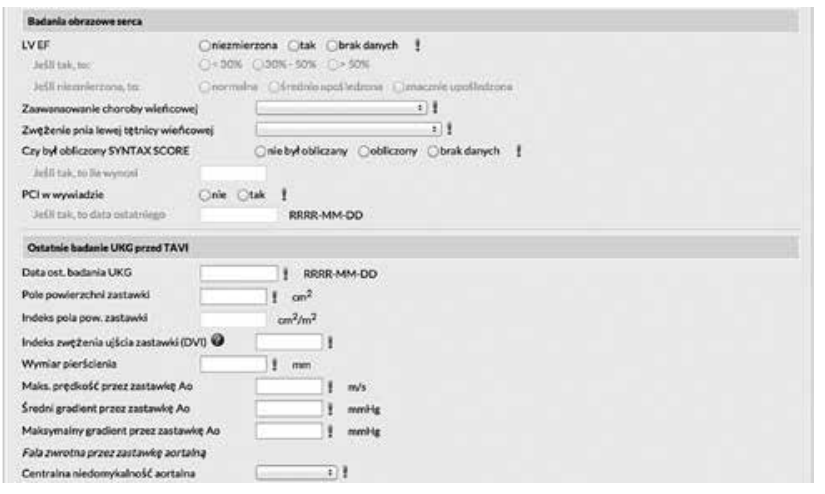

Fig. 6. Pre-procedural imaging

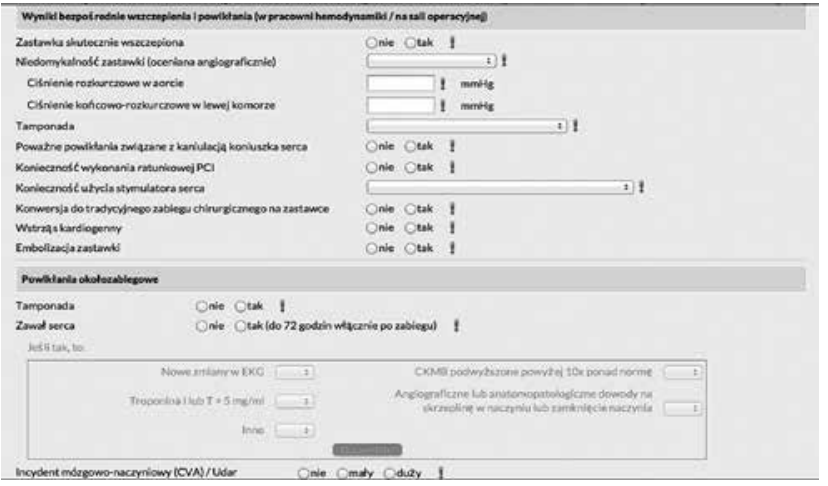

Fig. 8. Immediate TAVI results. Periprocedural complications

and coordination of medical databases. Additional documents, such as a written patient consent form, downloadable CRF, and POL-TAVI user's manual were prepared. All materials are published at POL-TAVI homepage and are easily accessible for Registry users.

The web-based POL-TAVI registry consists of three main parts, divided into 8 medical cards, collecting data on patient's history, in-hospital and follow-up period:

I. Baseline characteristics

1. Interview (Wywiad) (Fig. 3)

II. Procedural data

2. Assessment (Ocena) (Fig. 4)

3. Medical examinations (Badania) (Figs. 5, 6)

4. Procedure (Zabieg) (Figs. 7, 8)

5. Discharge (Wypis) (Fig. 9) 


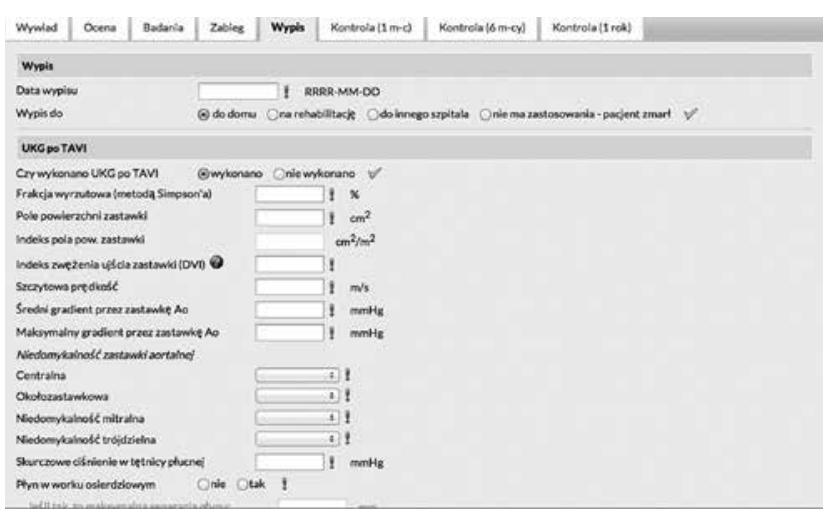

Fig. 9. Discharge

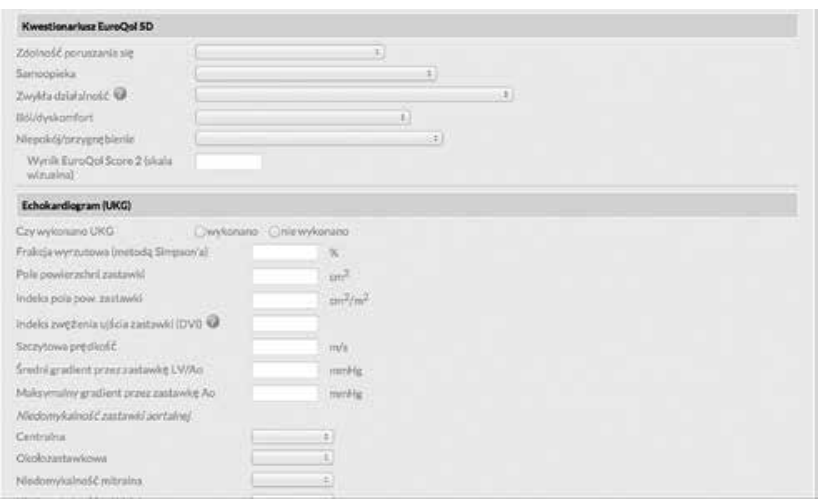

Fig. 11. Follow-up after 1 month: TAVI investigations, quality of life assessment

\section{Follow-up}

6. 1 month (Kontrola $1 \mathrm{~m}$-c) (Figs. 10, 11)

7. 6 months (Kontrola $6 \mathrm{~m}$-cy)

8. 12 months (Kontrola $12 \mathrm{~m}$-cy)

In 2016, the authors of this paper performed reconstruction of the Registry, updating it to the current needs and requirements, extending so far questionnaire - among others - for novel devices, adopting it to the current standardized endpoint definitions for TAVI - The Valve Academic Research Consortium-2 (VARC-2) [11]. Aside from ESC/ EACTS 2014 Guidelines, important evaluation criteria from AHA/ACC 2014 Guidelines were implemented (e.g. frailty scale, STS score) (Fig. 12).

The range of the survey was also extended for the transcatheter mitral valve replacement part, transforming the aortic registry into the first nation-wide database of transcatheter valve treatment in the country.

In total POL-TAVI collects over 370 parameters per patient in the baseline and procedural part together and nearly 100 (almost 300 in total) per patient in the follow-up card. A detailed list is available at www.poltavi.pl

The Registry, in its new edition, will be launched in January 2017.

\section{Data security}

Access to the POL-TAVI Registry is given only to authorized representatives of TAVI centers, upon receipt of written autho-

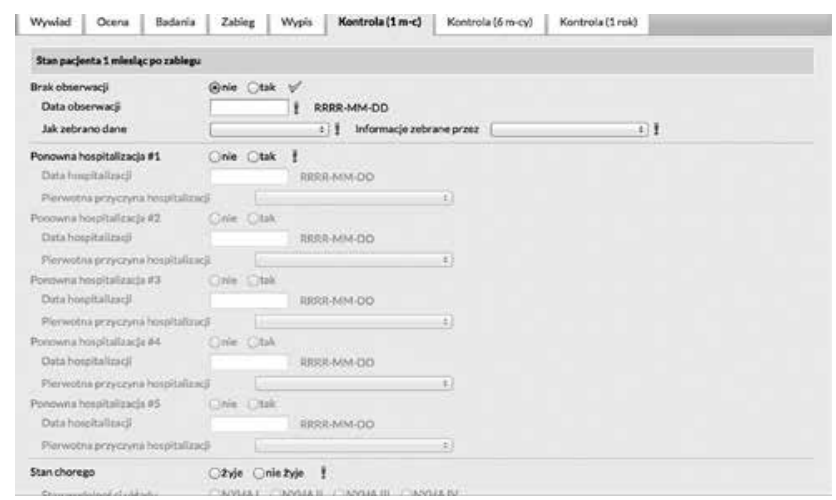

Fig. 10. Follow-up after 1 month - history of potential re-hospitalizations

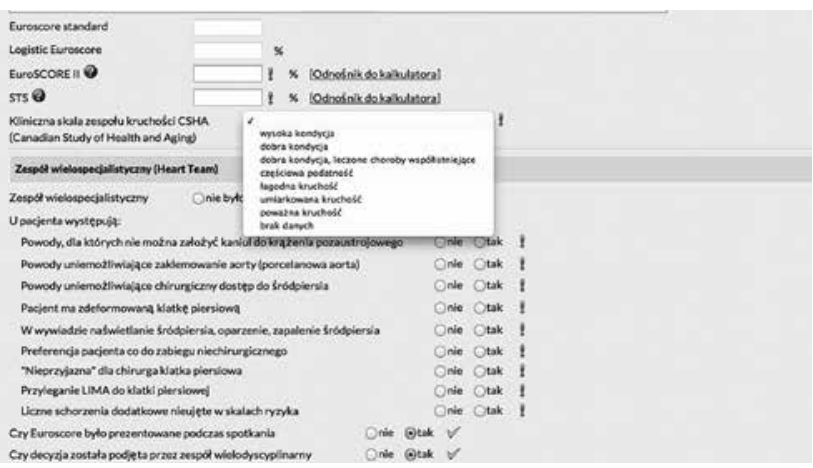

Fig. 12. Inclusion of STS Risk Calculator and Clinical Frailty Scale in updated POL-TAVI CRF - adaptation to 2014 AHA/ACC Guideline for the Management of Patients with VHD

rization by the POL-TAVI management team. Registered users log into their center's individual account. All data are secured in accordance with the national big data security regulations.

\section{Publications from POL-TAVI REGISTRY. e-Library}

The extensive material collected in the POL-TAVI Registry since January 1, 2013 (until December 31, 2015 including data on 1466 TAVI patients, 1471 TAVI procedures) constitutes a valuable source for multidimensional analysis and scientific research.

Use of POL-TAVI for scientific purposes (publications, presentation at national and international conferences, other) has been precisely defined in POL-TAVI regulations (available at www.poltavi.pl) and supervised by the Steering Committee.

Up to 2016 the following papers, based on POL-TAVI national results, were published or accepted for publication in peer-reviewed, international medical journals:

- Mitral and aortic regurgitation following transcatheter aortic valve replacement - Szymański et al. [12];

- Paravalvular leak after transcatheter aortic valve implantation (TAVI): short-term results. Data from Polish national POL-TAVI registry - Kleczyński et al. [13];

- Can TAVI patients receive aspirin monotherapy as patients after surgical aortic bioprosthesis implantation? Data from Polish Registry POL-TAVI - CzerwińskaJelonkiewicz et al. [14]; 
- Improvement of quality of life following transcatheter aortic valve implantation in elderly - multi-center study based on Polish National TAVI Registry - Stańska et al. [15]

Further manuscripts, documenting Polish TAVI results, are awaiting acceptance for publishing.

To provide researchers with easy access to literature on transcatheter valve treatment in Poland, on the initiative of Marian Zembala, chairman of the POL-TAVI Registry, in 2016 the first TAVI e-library, including all papers published so far on TAVI in Poland, was created. It is available at the POLTAVI homepage (open access - registration not required).

\section{Conclusions}

Transcatheter aortic valve implantation has been developed as an answer for clinical needs and expectations of patients disqualified by the TAVI team from conventional surgery. It constitutes a safe and effective therapeutic alternative for symptomatic AS patients with documented high risk. Performed both by cardiologists and cardiac surgeons as operators, working together as the TAVI team, this method, however, as a still new, challenging and costly option, requires careful and reliable multidimensional analysis.

The creation of the National Polish Cardiac-Cardiac Surgical Registry of Transcatheter Aortic Valve Implantation POL-TAVI has allowed for the first time for systematic collection and monitoring of Polish TAVI data, and evaluation of access of Polish patients to this method of treatment.

The Registry has enabled the assessment of quality of early and long-term results of treatment (using different devices), in patients with symptomatic AS and documented high risk or non-eligible for surgery due to severe co-morbidities or other contraindications (e.g. porcelain aorta).

Moreover, POL-TAVI has permitted reliable and thorough early, middle- and late-term assessment of TAVI safety, which matters especially in view of the more and more often observed premature calcification and damage of the implanted TAVI biological valve within 5 years after the procedure.

Finally, the POL-TAVI Registry has enabled, for the first time on such a scale, a systematic medical-economic-organizational analysis of the efficacy and profitability of this new alternative method of treatment - a method which should be dedicated exclusively to elderly high-risk patients. It needs to be highlighted that TAVI, without medical justification, should not replace the still fundamental, considered as safe and effective, surgical aortic valve implantation - evidence of which may be the data of the National Registry of Cardiac Surgery KROK and current SAVR outcomes: in 2015 in Poland 3505 patients underwent surgical aortic valve implantation (564 mini-invasively), with average in-hospital mortality of $3.7 \%$ (2.4\% respectively).

Having in mind the limited supplies and budget of the payer, and the level of health services reimbursement, careful and reasonable monitoring and systematic assessment of TAVI vs. SAVR application based on the objective earlyand long-term data from the registry are essential.
In sum, the POL-TAVI Registry constitutes an important and valuable tool for patients, medical professionals and the payer.

\section{Disclosure}

Authors report no conflict of interest.

\section{References}

1. Thaden JJ, Nkomo VI, Enriquez-Sarano M. The global burden of aortic stenosis. Prog Cardiovasc Dis 2014; 56: 565-571.

2. Wenaweser P, Praz F, Stortecky S, Transcatheter aortic valve implantation today and tomorrow. Swiss Med Wkly 2016; 146: w14299.

3. Nishimura RA, Otto CM, Bonow RO, Carabello BA, Erwin JP III, Guyton RA, O'Gara PT, Ruiz CE, Skubas NJ, Sorajja P, Sundt TM III, Thomas JD. 2014 AHA/ ACC Guideline for the management of patients with valvular heart disease: a report of the American College of Cardiology/American Heart Association Task Force on Practice Guidelines. Circulation 2014; 129: e521-643.

4. Vahanian A, Alfieri O, Andreotti F, Antunes MJ, Baron-Esquivias G, Baumgartner H, Borger MA, Carrel TP, De Bonis M, Evangelista A, Falk V, Lung B, Lancellotti P, Pierard L, Price S, Schafers HJ, Schuler G, Stepinska J, Swedberg K, Takkenberg J, Otto Von Oppell U, Windecker S, Zamorano JL, Zembala M. Guidelines on the management of valvular heart disease (version 2012). The Joint Task Force on the Management of Valvular Heart Disease of the European Society of Cardiology (ESC) and the European Association for CardioThoracic Surgery (EACTS). Eur. Heart J 2012; 33: 2451-2496.

5. Gilard $M$, Eltchaninoff $H$, lung $B$, Donzeau-Gouge $P$, Chevreul K, Fajadet J, Leprince P, Leguerrier A, Lievre M, Prat A, Teiger E, Lefevre T, Himbert D, Tchetche D, Carrié D, Albat B, Cribier A, Rioufol G, Sudre A, Blanchard D, Collet F, Dos Santos P, Meneveau N, Tirouvanziam A, Caussin C, Guyon P, Boschat J, Le Breton H, Collart F, Houel R, Delpine S, Souteyrand G, Favereau X, Ohlmann P, Doisy V, Grollier G, Gommeaux A, Claudel JP, Bourlon F, Bertrand B, Van Belle E, Laskar M; FRANCE 2 Investigators, Registry of transcatheter aortic-valve implantation in high-risk patients. N Engl J Med 2012; 366: 1705-1715.

6. Zembala M, Wilczek K, Przybylski R, Chodór P, Nadziakiewicz P, Krasoń M, Sadowski J, Dudek D, Kapelak B, Forysz D, Witkowski A, Demkow M, Chmielak Z, Kuśmierski K, Juraszyński Z, Bochenek A, Cisowski M, Trusz-Gluza M, Buszman P, Woś S, Kalarus Z, Poloński L, Gasior M, Opolski G, Ruzyłło W. POL-TAVI First--Polish report on transcatheter aortic valve implantation (TAVI) of Edwards-Sapien prosthesis in the first 19 high risk patients with severe aortic stenosis and co-morbidities. Kardiol Pol 2009; 67: 936-940.

7. Cribier A, Eltchaninoff H, Bash A, Borenstein N, Tron C, Bauer F, Derumeaux G, Anselme F, Laborde F, Leon MB. Percutaneous transcatheter implantation of an aortic valve prosthesis for calcific aortic stenosis: first human case description. Circulation 2002; 106: 3006-3008.

8. Kala P, Blaha M. Czech TAVI Registry - rationale and design. Cor et Vasa 2012; 54: e143-e150.

9. Vahanian A, lung B, Himbert D. Transcatheter aortic valve implantation: a treatment we are going to need! J Am Coll Cardiol 2013; 62: 1013-1014.

10. Di Mario C, Eltchaninoff H, Moat N, Goicolea J, Ussia GP, Kala P, Wenaweser $P$, Zembala M, Nickenig G, Alegria Barrero E, Snow T, lung B, Zamorano P, Schuler G, Corti R, Alfieri O, Prendergast B, Ludman P, Windecker S, Sabate M, Gilard M, Witowski A, Danenberg H, Schroeder E, Romeo F, Macaya C, Derumeaux G, Maggioni A, Tavazzi L; Transcatheter Valve Treatment Sentinel Registry (TCVT) Investigators of the EURObservational Research Programme (EORP) of the European Society of Cardiology. The 2011-12 pilot European Sentinel Registry of Transcatheter Aortic Valve Implantation: in-hospital results in 4,571 patients. Eurolntervention 2013; 8: 1362-1371.

11. Kappetein AP, Head SJ, Généreux P, Piazza N, van Mieghem NM, Blackstone EH, Brott TG, Cohen DJ, Cutlip DE, van Es GA, Hahn RT, Kirtane AJ, Krucoff MW, Kodali S, Mack MJ, Mehran R, Rodés-Cabau J, Vranckx P, Webb JG, Windecker S, Serruys PW, Leon MB; Valve Academic Research Consortium (VARC)-2. Updated standardized endpoint definitions for transcatheter aortic valve implantation: the Valve Academic Research Consortium-2 consensus document (VARC-2). Eur J Cardiothorac Surg 2012; 42: S45-S60.

12. Szymański P, Hryniewiecki T, Dąbrowski M, Sorysz D, Kochman J, Jastrzębski J, Kukulski T, Zembala M. Mitral and aortic regurgitation following transcatheter aortic valve replacement. Heart Heart Online 2016 Feb; 10.1136/ heartjnl-2015-308842. 
13. Kleczyński P, Zasada W, Bagieński M, Rzeszutko Ł, Sorysz D, Sobczyński R, Trębacz J, Kapelak B, Zembala M, Dudek D. Paravalvular leak after transcatheter aortic valve implantation (TAVI). Short-term results. Data from Polish national POL-TAVI registry. Cardiol J 2016; 23: 163-168.

14. Czerwińska-Jelonkiewicz K, Zembala M, Dąbrowski M, Witkowski A, Ochała A, Kochman J, Dudek D, Kübler P, Jagielak D, Stępińska J. Can TAVI patients receive aspirin monotherapy as patients after surgical aortic bioprosthesis implantation? Data from Polish Registry - POL-TAVI. Int J Cardiol 2017; 227: 305-311.
15. Stańska A, Jagielak D, Brzeziński M, Zembala M, Wojakowski W, Kochman J, Huczek Z, Witkowski A, Zembala M. Improvement of quality of life following transcatheter aortic valve implantation in elderly - multi-centre study based on Polish national TAVI registry. Kardiol Pol 2016 Nov 23 DOI: 10.5603/ KP.a2016.0164. 